DOI: $10.2478 / \mathrm{v} 10014-009-0017-\mathrm{x}$

Agrovoc descriptors: Trialeurodes vaporariorum; Encarsia formosa; identification; classification; geographical distribution; biological control; pest control; natural enemies; indigenous organisms; greenhouses; plant protection

Agris category code: $\mathrm{H} 10$

\title{
First massive occurrence of greenhouse whitefly parasitoid, Encarsia formosa Gahan (Hymenoptera: Aphelinidae) on greenhouse whitefly, Trialeurodes vaporariorum [Westwood] (Homoptera: Aleyrodidae) in Slovenia
}

\author{
Katarina $\operatorname{KOS}^{1}$, Željko TOMANOVIĆ ${ }^{2}$, Helena ROJHT ${ }^{3}$, Matej VIDRIH ${ }^{4}$, Stanislav TRDAN ${ }^{5}$
}

Received: February 6, 2009; accepted: June 23, 2009

Članek je prispel: 6. februarja 2009; sprejet: 23. junija 2009

\begin{abstract}
In 2008, massive population of parasitoid Encarsia formosa was found for the first time in the greenhouses on the Laboratory Field of Biotechnical Faculty in Ljubljana (Slovenia). This species is known for a long time as effective natural enemy of the greenhouse whitefly, Trialeurodes vaporariorum, and other whiteflies in different parts of the world. 1306 wasps from genus Encarsia were found in nymphs of greenhouse whitefly. The most numerous was E. formosa (934 individuals), following by 367 individuals of E. tricolor, 4 males of $E$. inaron and a male of $E$. longicornis. Greenhouse whitefly parasitoid was determined on 14 host plants in the greenhouse and E. tricolor on 11 host plants in the greenhouse and on one host plant in the field. E. inaron and $E$. longicornis appeared only on one host plant in a greenhouse. For the time being the use of wasp E. formosa is not yet permitted in controlling greenhouse whitefly in Slovenia, but there is possibility to include it in the programs of biological control of pests on ornamentals and vegetable plants in the greenhouses. Consequently, the use of chemical insecticides will be reduced.
\end{abstract}

Key words: greenhouse whitefly parasitoid, Encarsia formosa, greenhouse whitefly, Trialeurodes vaporariorum, biological control, natural enemies, indigenous species, greenhouse, Slovenia

\section{IZVLEČEK}

PRVA ŠTEVILČNEJŠA NAJDBA NAJEZDNIKA

RASTLINJAKOVEGA ŠČITKARJA, Encarsia formosa Gahan (Hymenoptera: Aphelinidae) NA RASTLINJAKOVEM

ŠČITKARJU, Trialeurodes vaporariorum [Westwood] (Homoptera: Aleyrodidae) V SLOVENIJI

$\mathrm{V}$ rastlinjakih na Laboratorijskem polju Biotehniške fakultete $\mathrm{v}$ Ljubljani smo v letu 2008 prvič našli številčnejšo populacijo parazitoida Encarsia formosa, ki je v svetu dobro znan naravn sovražnik rastlinjakovega ščitkarja, Trialeurodes vaporariorum, in nekaterih drugih vrst ščitkarjev. V ličinkah rastlinjakovega ščitkarja smo našli 1306 osic iz rodu Encarsia. Najbolj številčni so bili osebki vrste $E$. formosa (934 osebkov), našli pa smo še 367 osebkov vrste $E$. tricolor, 4 samce vrste $E$. inaron in enega samca vrste $E$. longicornis. Predstavnike vrste $E$. formosa smo našli na 14 gostiteljskih rastlinah $\mathrm{v}$ rastlinjakih, vrsto E. tricolor pa na 11 vrstah gostiteljskih rastlin $\mathrm{v}$ rastlinjakih in na eni rastlinski vrsti na prostem, medtem ko sta se vrsti E. inaron in E. longicornis pojavili le na eni rastlinski vrsti v rastlinjaku. V Sloveniji uporaba osice E. formosa za zatiranje rastlinjakovega ščitkarja še ni razširjena, vendar bi jo lahko vključili v programe biotičnega varstva okrasnih rastlin in vrtnin $\mathrm{v}$ zavarovanih prostorih in tako zmanjšali uporabo insekticidov.

Ključne besede: najezdnik rastlinjakovega ščitkarja, Encarsia formosa, rastlinjakov ščitkar, Trialeurodes vaporariorum, biotično varstvo, naravni sovražniki, domorodna vrsta, rastlinjak, Slovenija

\footnotetext{
1 Teach. Assist., B. Sc., Jamnikarjeva 101, SI-1111 Ljubljana; E-mail: katarina.kos@bf.uni-lj.si

2 Assoc. Prof., Ph. D., University of Belgrade, Faculty of Biology, Studentski trg 16, SER-11000 Belgrade

3 Teach. Assist., young reseacher, Jamnikarjeva 101, SI-1111 Ljubljana

4 Teach. Assist., Ph. D., ibid.

5 Assoc. Prof., Ph. D., ibid,
} 


\section{INTRODUCTION}

Family of whiteflies (Aleyrodidae) comprises important pests, which attack many cultivated and wild-growing plant species in the open and in the greenhouses. They have incomplete development and adults are around $2 \mathrm{~mm}$ in length and have totally white wings, which are covered with waxy coating (Peters, 1993; Succop, 1997). Greenhouse whitefly, Trialeurodes vaporariorum (Westwood), causes direct damage with sucking sap from the plants, resulting in a yellow mottling on the surface of the leaf, as well as leaf loss, wilting and stunting. Its indirect damage is made by transmission of viruses and producing honeydew, which attract black fungi of sooty molds, Cladosporium spp. (Succop, 1997).

Parasitoids from genus Encarsia are probably one of the first practically applied biological agents in plant protection. Genus Encarsia belongs to subfamily Aphelinidae, family Braconidae and order Hymenoptera. Encarsia formosa Gahan is a parasitoid, which is, as biological agent in controlling greenhouse whitefly (Fig.3), spread in different parts of the world (van Lenteren and Woets, 1988; van Lenteren et al., 1996). It is used against this pest on vegetable and ornamental plants in greenhouses. Commercial usage of this parasitoid started already around 1920 , but after approximately 20 years its interest waned due to intensive development of chemical insecticides. After 1970, interest in greenhouse whitefly parasitoid was reinitiated and its usage in plant protection was expanded in 1993 to 4800 hectares of greenhouse area (van Lenteren and Woets, 1988; van Lenteren, 1995).

Adult wasps of parasitoid (Fig. 1) feed on honeydew and with excreted body fluids of young larvae (L1) of greenhouse whitefly, and doing so they kill them many. If many wasps appear, previously mentioned way of feeding is used also on higher developmental stages of whitefly larvae. To feed host, Encarsia formosa wasps wound larvae by probing with the ovipositor and feeds from wounds and that way they are provided with proteins. In this way they kill almost $3 / 4$ of whiteflies. Larvae of Encarsia formosa feed with the internal content of parasitized whiteflies, eat all the organs and leave only outer armor (Fig. 2) in which they pupate afterward (Milevoj, 2007).

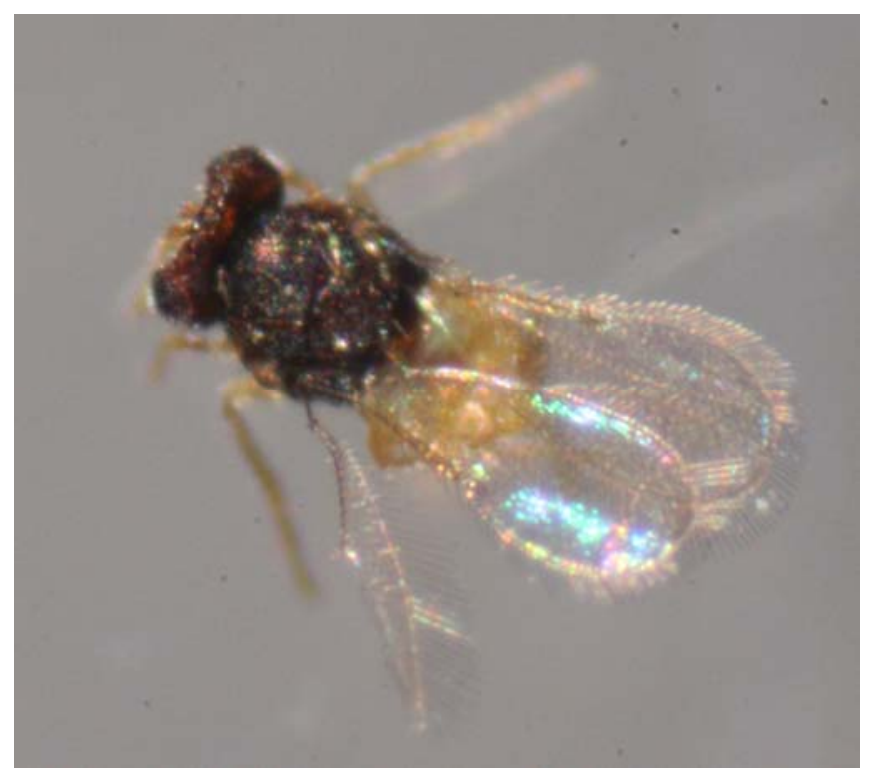

Figure 1: Adult of Encarsia formosa Gahan (Photo by K. Kos) 

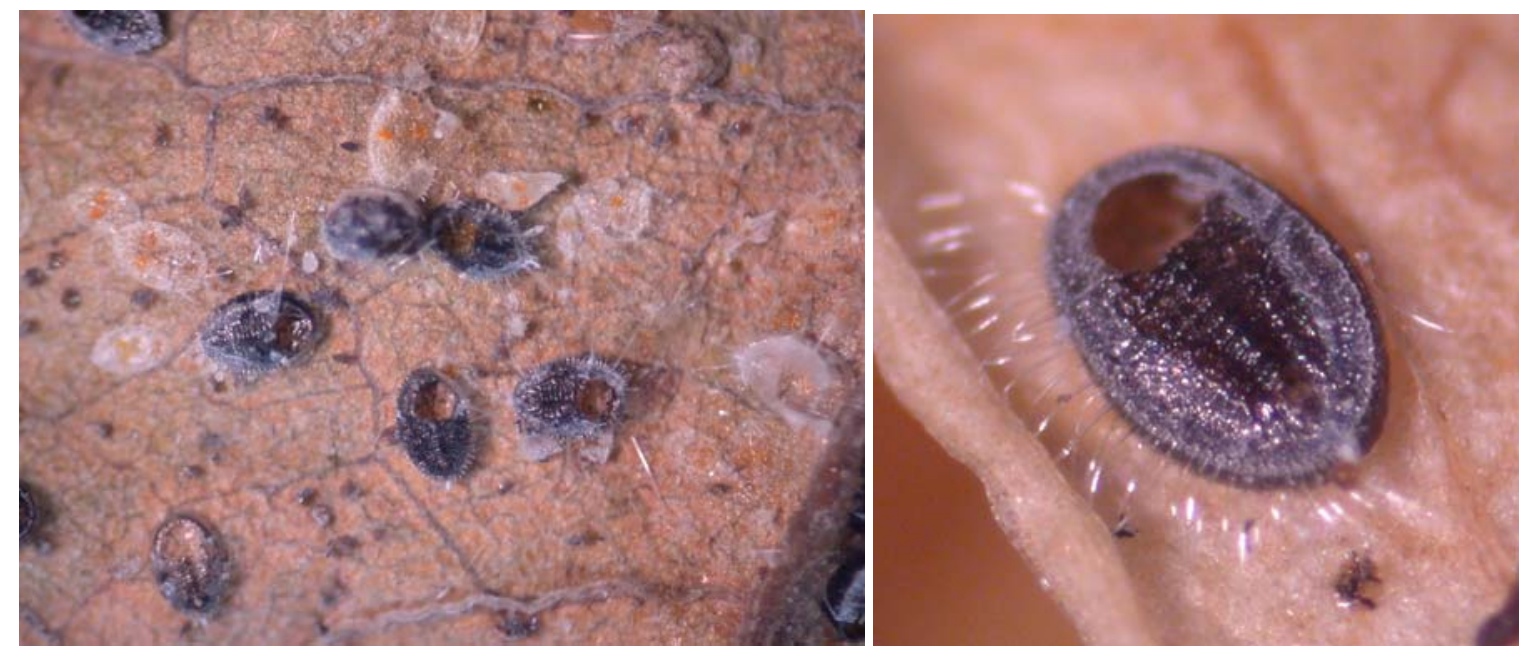

Figure 2: Empty pupal cases of greenhouse whitefly on celery (Photo by K. Kos)



Figure 3: Life cycle of Encarsia formosa Gahan on greenhouse whitefly (Photo by K. Kos)

Encarsia formosa parasitizes at least 15 whitefly species, which belong to 8 genera. The most important hosts of this natural enemy are Trialeurodes vaporariorum, Aleyrodes proletella (L.), Bemisia argentifolii Bellows \& Perring and Bemisia tabaci (Gennadius) (Schauff and Evans, 1996), but on the other hand greenhouse whitefly parasitoid is also parasitized by three hyperparasitoids: Signiphora coquilletti
Ashmead (Woolley and Vet, 1981), Encarsia pergandiella Howard (Buijs et al., 1981) and Encarsia tricolor Förster. The later can be also a primary parasitoid, autoparasitoid or hyperparasitoid (Avilla et al., 1991).

In August 1994, Encarsia formosa was first recorded in Slovenia, namely on tomato plants grown on Laboratory

Acta agriculturae Slovenica, 93 - 3, september 2009 
Field of Biotechnical Faculty in Ljubljana, which were heavily attacked by greenhouse whitefly (Milevoj and Osvald, 1996). But in years which followed, this natural enemy was impossible to find. Target plants which are mentioned by Milevoj and Osvald (1996) as most suitable for introduction of Encarsia formosa are pepper, egg plant, bean, cucumber, tomato and rose. It is very important to monitor the first attack of greenhouse whitefly with yellow sticky boards or indicator plants, which are put into the greenhouse with the aim of easier detection of the pest. Among such plant species we can also include fuchsia plants (Fuchsia spp.), which have ability of attracting first specimens of whitefly in the greenhouse. The effect of biological control is seen after around 3 weeks. But the strategy of plant protection must be harmonized in a greenhouse. Namely, the wasp is very sensitive to multiple application of fungicides and also foliage fertilizers can do harm to it (Milevoj, 2007).

The aim of our research was to find the indigenous species of natural enemies in greenhouses in Slovenia and in nymphs of greenhouse whitefly from greenhouses on Laboratory Field of Biotechnical Faculty in Ljubljana the high number of greenhouse whitefly parasitoid, Encarsia formosa Gahan, and some other Encarsia members was found.

\section{MATERIAL AND METHODS}

At the end of summer 2008 we investigated the presence of parasitoids on greenhouse whitefly, Trialeurodes vaporariorum, in a greenhouse on Laboratory Field of Biotechnical Faculty in Ljubljana $\left(46^{\circ} 04^{\prime} \mathrm{N}, 14^{\circ} 31^{\prime}\right.$ E). Vegetables, ornamental plants and weeds from the glass and plastic greenhouses were included in a research. One random sample was taken also from the cabbage, attacked by cabbage whitefly, Aleyrodes proletella L., grown in the open (village Trstenik near Golnik, $46^{\circ} 20^{\prime} \mathrm{N}, 14^{\circ} 20 \mathrm{E}$ ).
The sampling method was adapted to the development of parasitoids inside their hosts. We placed parasitized pupal cases of greenhouse whitefly together with the host plant into the plastic pots, similar as we collected the samples of aphid parasitoids (Brajković and Tomanović, 2005; Kos, 2007; Kos et al., 2008). After 3 to 4 weeks we removed dead parasitoids from genus Encarsia from the labeled samples. The samples were sent to Natural History Museum in Belgrade (Serbia) for identification (Aleksandar Stojanović).

\section{RESULTS WITH DISCUSSION}

In the greenhouses on the Laboratory Field of Biotechnical Faculty, the parasitoids of greenhouse whitefly were found in high number. We collected 14 plant species, on which black pupal cases of whiteflies were observed and for which we assumed to be parasitized.

The total number of female wasps had amounted 1306 individuals. Encarsia formosa was the most abundant (934 individuals), namely 930 females and 4 males were identified from the samples (Table 1). The second most abundant species was Encarsia tricolor Förster with 367 individuals, from which 145 were females and 222 were males. We also found 4 males of Encarsia inaron (Walker) and a male of Encarsia longicornis Mercet.

Parasitoid Encarsia formosa was found on 14 host plants from the greenhouse (Fig. 4) and Encarsia tricolor on 11 host plants from the greenhouse and on cabbage in the open. Encarsia inaron and Encarsia longicornis appeared only on one host plant, i.e. tomato and cherry tomato, respectively, both from the greenhouse. One male and 3 females of Encarsia tricolor was collected also from the nymphs of cabbage whitefly, which attacked cabbage (Brassica oleracea var. capitata) in village Trstenik near Golnik. 
First massive occurrence of greenhouse whitefly parasitoid, Encarsia formosa Gahan (Hymenoptera: Aphelinidae)...

Table 1: Encarsia species and number of their males and females from greenhouse whitefly, Trialeurodes vaporariorum, collected from 14 different host plants of the pest. The samples were taken from the greenhouses on the Laboratory Field of Biotechnical Faculty in Ljubljana, Slovenia.

\begin{tabular}{|c|c|c|c|c|c|}
\hline \multicolumn{2}{|r|}{ Host plant } & \multicolumn{4}{|c|}{ Parasitoid } \\
\hline $\begin{array}{l}\text { Common } \\
\text { name }\end{array}$ & Latin name & Species & $\begin{array}{l}\text { Number } \\
\text { of males }\end{array}$ & $\begin{array}{l}\text { Number } \\
\text { of females }\end{array}$ & Total \\
\hline \multirow{2}{*}{$\begin{array}{c}\text { St John's } \\
\text { wort }\end{array}$} & \multirow{2}{*}{$\begin{array}{c}\text { Hypericum perforatum } \\
\text { L. } \\
\end{array}$} & Encarsia formosa Gahan & 1 & 112 & 113 \\
\hline & & Encarsia tricolor Förster & 50 & & $\mathbf{5 0}$ \\
\hline $\begin{array}{l}\text { Common } \\
\text { buckwheat }\end{array}$ & $\begin{array}{c}\text { Fagopyrum esculentum } \\
\text { Moench }\end{array}$ & Encarsia formosa Gahan & & 45 & 45 \\
\hline \multirow[t]{3}{*}{ Tomato } & \multirow{3}{*}{$\begin{array}{l}\text { Lycopersicon } \\
\text { esculentum Mill. }\end{array}$} & Encarsia formosa Gahan & & 208 & 208 \\
\hline & & Encarsia tricolor Förster & 51 & 35 & 86 \\
\hline & & Encarsia inaron (Walker) & 4 & & 4 \\
\hline \multirow[t]{2}{*}{ Basil } & \multirow{2}{*}{$\begin{array}{l}\text { Ocimum polystachion } \\
\text { L. }\end{array}$} & Encarsia formosa Gahan & & 62 & 62 \\
\hline & & Encarsia tricolor Förster & 1 & & 1 \\
\hline \multirow{2}{*}{$\begin{array}{l}\text { Common } \\
\text { chicory }\end{array}$} & \multirow[t]{2}{*}{ Cichorium intybus L. } & Encarsia formosa Gahan & & 105 & 105 \\
\hline & & Encarsia tricolor Förster & 2 & & 2 \\
\hline Celery & Apium graveolens L. & Encarsia formosa Gahan & & 10 & 10 \\
\hline \multirow{3}{*}{$\begin{array}{l}\text { Cherry } \\
\text { tomato }\end{array}$} & \multirow{3}{*}{$\begin{array}{l}\text { Lycopersicon } \\
\text { esculentum Mill. }\end{array}$} & Encarsia formosa Gahan & & 23 & 23 \\
\hline & & Encarsia tricolor Förster & 1 & 19 & 20 \\
\hline & & Encarsia longicornis Mercet & 1 & & 1 \\
\hline Fuchsia & Fuchsia spp. & Encarsia formosa Gahan & & 85 & 85 \\
\hline \multirow[t]{2}{*}{ Bean } & \multirow[t]{2}{*}{ Phaseolus vulgaris L. } & Encarsia formosa Gahan & 3 & 187 & 190 \\
\hline & & Encarsia tricolor Förster & 38 & & 38 \\
\hline \multirow[t]{2}{*}{ Asparagus } & \multirow[t]{2}{*}{ Asparagus officinalis L. } & Encarsia formosa Gahan & & 6 & 6 \\
\hline & & Encarsia tricolor Förster & 2 & & 2 \\
\hline \multirow[t]{2}{*}{ Marjoram } & \multirow{2}{*}{$\begin{array}{c}\text { Majorana hortensis } \\
\text { Moench }\end{array}$} & Encarsia formosa Gahan & & 8 & 8 \\
\hline & & Encarsia tricolor Förster & 26 & & 26 \\
\hline \multirow[t]{2}{*}{ Holy basil } & \multirow[t]{2}{*}{ Ocimum sanctum L. } & Encarsia formosa Gahan & & 70 & 70 \\
\hline & & Encarsia tricolor Förster & 18 & 4 & 22 \\
\hline \multirow[t]{2}{*}{ Cucumber } & \multirow[t]{2}{*}{ Cucumis sativa L. } & Encarsia formosa Gahan & & 1 & 1 \\
\hline & & Encarsia tricolor Förster & 13 & 11 & 24 \\
\hline \multirow[t]{2}{*}{ Pepper } & \multirow[t]{2}{*}{ Capsicum annuum L. } & Encarsia formosa Gahan & & 8 & 8 \\
\hline & & Encarsia tricolor Förster & 20 & 76 & 96 \\
\hline
\end{tabular}

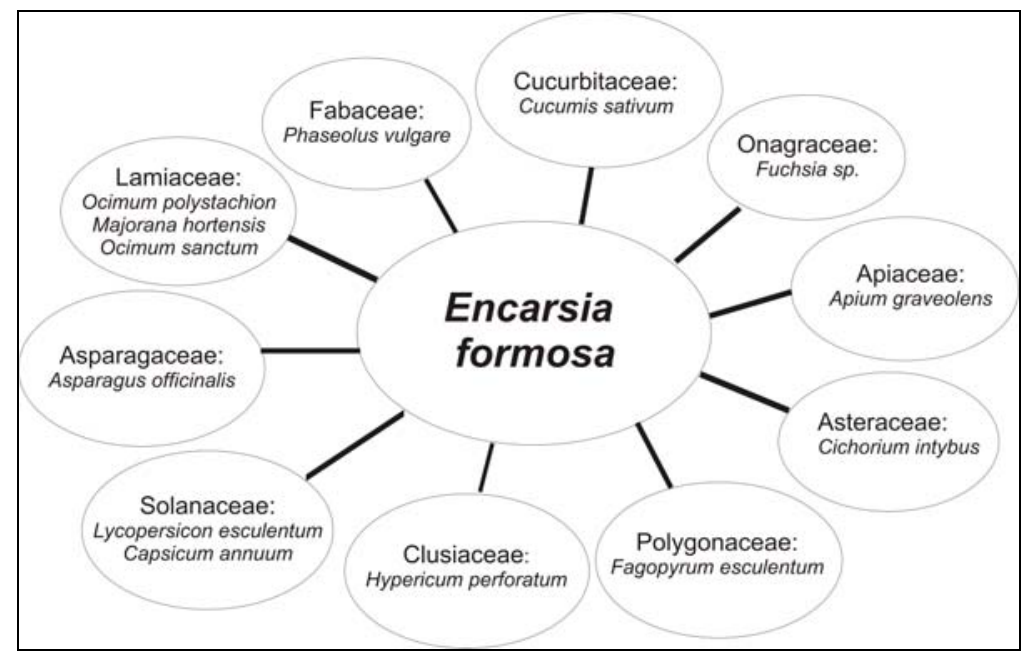

Figure 4: Host plants of greenhouse whitefly, Trialeurodes vaporariorum, from the greenhouses, in which greenhouse whitefly parasitoid, Encarsia formosa, was found. 


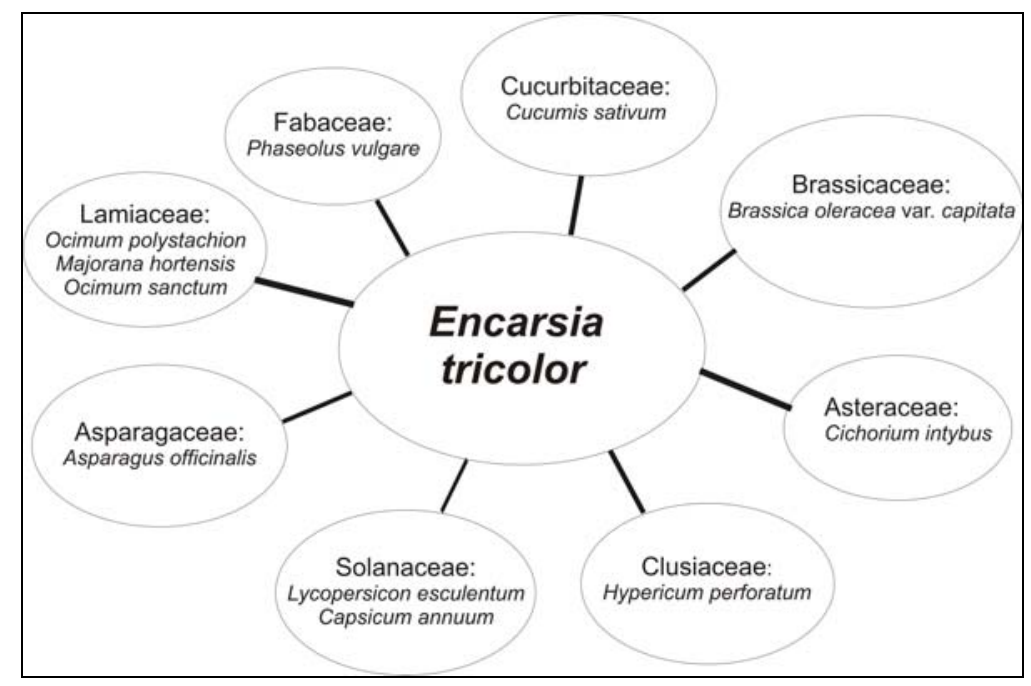

Figure 5: Host plants of greenhouse whitefly, Trialeurodes vaporariorum, from the greenhouses, in which Encarsia tricolor was found. The same parasitoid was recored also on cabbage, attacked by cabbage whitefly, Aleyrodes proletella.

\section{CONCLUSIONS}

In 2008, high number of parasitoid wasps from genus Encarsia was found on vegetables and ornamental plants in greenhouses on Laboratory Field of Biotechnical Faculty in Ljubljana. Encarsia formosa, which is considered to be one of the most important biological agent in controlling whiteflies in greenhouses (Hoddle, 1997), was the most abundant Encarsia species in our research. Most often it is used in controlling greenhouse whitefly, Trialeurodes vaporariorum, and tobacco whitefly, Bemisia tabaci (Hoddle et al., 1998).

Entire number of wasps, we found, was 1308, from which 934 individuals belonged to the species Encarsia formosa (930 females and 4 males) and 367 individuals were identified as Encarsia tricolor (145 females and 222 males). We also recorded 4 males of Encarsia inaron and a male of Encarsia longicornis. We ascertained Encarsia formosa on 14 different host plants in greenhouse and Encarsia tricolor on 11 host plants in greenhouse and on cabbage, which was grown outdoor in village Trstenik in Gorenjska region.

Greenhouse whitefly represents large problems in growing vegetables and ornamental plants in greenhouses in Slovenia. For this reason the use of Encarsia formosa in a frame of integrated plant protection against the pest mentioned could be practiced as an important measure in reducing damage. Introduction of parasitoid $E$. formosa is relatively simple and this biological control agent can effectively reduce the population of whitefly. Use of $E$. formosa is a good example of reduction of damage, caused by greenhouse whitefly, and at the same time there is no need for relying solely on insecticides (Succop, 1997).

\section{ACKNOWLEDGEMENT}

This work was done within Horticulture No P4-00130481, a program funded by the Slovenian Research Agency, and within the project CRP V4-0524 granted by Slovenian Research Agency and Ministry of Agriculture, Food and Forestry of R Slovenia. Part of the research was funded within Professional tasks from the field of plant protection, the program funded by the Ministry of Agriculture, Forestry and Food of R Slovenia Phytosanitary Administration of the Republic of Slovenia. 


\section{REFERENCES}

Avilla J., Anandon J., Sarasua M.J., Albajes, R. 1991. Egg allocation of the autoparasitoid Encarsia tricolor at different relative densities of the primary host (Trialeurodes vaporariorum) and two secondary hosts (Encarsia formosa and E. tricolor). Entomol. Exp. Appl. 59: 219-27.

Brajković, M., Tomanović, Ž. 2005. Entomološki praktikum. Metode sakupljanja, preparovanja insekata. Beogr., Biol. fak., Univ. Beogr.: 106 p.

Buijs, M.J., Pirovano, I., van Lenteren, J.C. 1981. Encarsia pergandiella, a possible biological control agent for the greenhouse whitefly, Trialeurodes vaporariorum. A study on intra and interspecific host selection. Med. Fac. Landbouww. Rijksuniv. Gent 46: 465-75.

Hoddle M. S. 1997. Encarsia formosa (Hymenoptera: Aphelinidae). In: Weeden, C. (ur.): Biological control: a guide to natural enemies in North America, Cornell University. Infoseek http://www.nysaes.cornell.edu/ent/biocontrol/parasitoids/ eformosa.html (30.1. 2009).

Hoddle, M. S., VanDriesche, R. G., Sanderson, J. P. 1998. Biology and use of the whitefly parasitoid Encarsia formosa. Annu. Rev. Entomol. 43: 645-669.

Kos, K. 2007. Aphids (Aphididae) and their parasitoids in a vegetable ecosystem. Grad. Th.,, Univ. Ljubl., Biotech. Fac., Dept. Agronomy: 69 p. [Slovenian].

Kos, K., Tomanović, Ž., Petrović-Obradović, O., Laznik, Ž. Vidrih, M., Trdan S. 2008. Aphids (Aphididae) and their parasitoids in selected vegetable ecosystems in Slovenia. Acta Agric. Slov., 91: 15-22.
Milevoj, L., Osvald, J. 1996. Methods for integrated culitvation and control of horticultural crops. Proceed. Symp. New challenges in field crop production. Ljubl., Biotech. Fac., Dept. Agron.: 313-317 [Slovenian].

Milevoj, L. 2007. Biological control of pests in greenhouses. Univ. Ljubl., Biotech. Fac., Dept. Agron.: 51 p. [Slovenian].

Peters, T. M. 1993. Insects and human society. Univ. Mass.: $450 \mathrm{p}$.

Succop, B. 1997. The parasitism of greenhouse whitefly, Trialeurodes vaporariorum, by the parasitic wasp, Encarsia formosa: a biological control method in greenhouses. Insect Behavior Review Articles 1997.

http://www.colostate.edu/Depts/Entomology/courses/en5 07/papers_1997/succop.html. (30.1.2009)

van Lenteren, J. C., van Roermund, H. J. W., Sutterlin S. 1996. Biological control of greenhouse whitefly (Trialeurodes vaporariorum) with the parasitoid Encarsia formosa: How does it work? Biol. Control 6: 110.

van Lenteren, J. C., Woets, J. 1988. Biological and integrated control in greenhouses. Annu. Rev. Entomol. 33: 239-69.

van Lenteren J. C. 1995. Integrated pest management in protected crops. In: Dent, D. R. (ed.). Integrated Pest Management: Principles and Systems Development. London, Chapman \& Hall. 311-343.

Woolley, J. B.,Vet, L. E. M. 1981. Postovipositional webspinning behavior in a hyperparasite Signiphora coquelletti Ashmead (Hymenoptera: Signiphoridae). Neth. J. Zool. 31: 627-633. 